\title{
WAIVER OF A PREVIOUSLY UNRECOGNIZED DEFENSE: MUST LAWYERS BE SEERS?
}

For several years before New York Times $C o . v$. Sullivan ${ }^{1}$ there was a growing suspicion in the legal profession ${ }^{2}$ that constitutional defenses might be successfully invoked in some libel cases. New York Times confirmed that suspicion by holding that the United States Constitution "prohibits a public official from recovering damages for a defamatory falsehood relating to his official conduct unless he proves that the statement was made with actual malice-that is, with knowledge that it was false or with reckless disregard of whether it was false or not." 3 The question whether the defendant in a libel case whose trial ${ }^{4}$ occurred before the New York Times decision waived the constitutional right enunciated in that case by failing to assert a general constitutional defense at trial arose in Curtis Publishing Co. v. Butts. ${ }^{5}$ As soon as Neze York Times was decided, defendant Curtis moved for a new trial, claiming for the first time that Butts, athletic director at a state university, was a public official and that the first amendment prohibited his recovery in the absence of a finding of actual malice. The trial court denied the motion on the grounds, among others, that Butts was not a public official as contemplated by New York Times. ${ }^{6}$

1 New York Times Co. v. Sullivan, 376 U.S. 254 (1964), reversing 273 Ala. 656, 144 So. $2 \mathrm{~d} 25$ (1962).

2 See, e.g., Justice Black and First Amendment "Absolutes": A Public Interview, 37 N.Y.Ư.L. REv. 549, 558 (1962).

3 New York Times Co. v. Sullivan, 376 U.S. 254, 279 (1964).

4 Butts v. Curtis Publishing Co., 225 F. Supp. 916 (N.D. Ga. 1964). Plaintiff Butts was Athletic Director at the University of Georgia, and Curtis published an article called The Story of a College Football Fix, in the Saturday Evening Post, March 23, 1963, p. 80, which stated that Butts had given information regarding the Georgia football team's strategy to a rival coach. The trial resulted in a jury verdict for the plaintiff in the amount of $\$ 60,000$ general damages and $\$ 3,000,000$ punitive damages. Pursuant to the district court's order, the plaintiff filed a remittitur of all punitive damages in excess of $\$ 400,000$. On January 22,1964 the district court overruled the defendant's motion for new trial, entering judgment for the plaintiff in the amount of $\$ 460,000$.

5 Curtis Publishing Co. v. Butts, 351 F.2d 702 (5th Cir. 1965), petition for rehearing denied, 351 F.2d at 733, petition for cert. filed, 33 U.S.L. WEEK 3223 (U.S. Dec. 21, 1965) (No. 814).

6 Butts v. Curtis Publishing Co., 242 F. Supp. 390, 394 (1964). The defendant filed two motions for new trial pursuant to FED. R. CIV. P. 60(b) (2), one on Feb. 28, 1964, the other after March 9, 1964, when New York Times was decided. The latter asserted the constitutional right enunciated in New York Times. Both motions were denied on April 7, 1964. The trial judge concluded that, even if Butts were a public official under the New York Times rule, there would be no necessity for a new trial, because there was ample evidence from which the jury could have concluded that there was actual malice. 242 F. Supp. at 395 . But see 351 F.2d at 723 (Rives, J., dissenting) (maintaining that the jury charge did not adequately frame the issue of actual malice under the New York Times standard). 
The Court of Appeals for the Fifth Circuit refused to speak to the constitutional question on its merits, holding that Curtis had waived its right to challenge the judgment on the constitutional grounds declared in New York Times by failing to raise any first and fourteenth amendment argument at trial. Because the Alabama law firm which had represented the New York Times Company collaborated with defendant's counsel in the Butts case, ${ }^{7}$ and because of the contemporary awareness of such constitutional arguments, ${ }^{8}$ the court concluded that Curtis must have considered raising a constitutional defense and must have decided not to do so. ${ }^{9}$

While a constitutional right or defense, as well as any other right or defense, is usually forfeited by a party's failure to assert it seasonably at trial, 10 the Supreme Court has said that "a change in the law between a ... [trial] and an appellate decision requires the appellate court to apply the changed law." 11 The circuit court did not decide whether New York Times did constitute such a change, ${ }^{12}$ but there is little doubt that it did. ${ }^{13}$ The relevant portions of Georgia libel law are substantively the same as the Alabama law declared unconstitutional in that case ${ }^{14}$-both states were "fair comment" jurisdictions. ${ }^{15}$ It is clear that without a finding that Curtis had waived the constitutional argument, the circuit court would have had to consider the case in the light of Nere York Times.

In Hormel v. Helvering, ${ }^{16}$ a case which is procedurally similar to the Butts case, the Supreme Court did apply changed law and did not hold that the defendant had waived the argument asserted for the first time on appeal. The Court allowed the Commissioner of Internal Revenue to rely

7351 F.2d at 710 .

8 Id. at 711 .

${ }^{9} I d$. at 710 .

10 E.g., Yakus v. United States, 321 U.S. 414, 444 (1944).

11 Ziffrin, Inc. v. United States, 318 U.S. 73, 78 (1943) ; Vandenbark v. OwensIllinois Glass Co., 311 U.S. 538, 543 (1941) (when state supreme court changes applicable law between trial and appeal in federal courts, circuit court must apply the new law). The classic case is United States v. The Schooner Peggy, 5 U.S. (1 Cranch) 103, 109 (1801) (treaty intervening between trial and final appeal dissolved rights of plaintiffs in the schooner). This rule should not be confused with the doctrine called "law of the case," a phrase used in several senses, one of which is that an appellate court will not reconsider its own rulings of law on a subsequent appeal in the same case. An intervening change of law is a widely recognized basis for not following the prior ruling. Developments in the Lav-Res Judicata, 65 HARV. L. REv. 818, 822 (1952).

12351 F.2d at 711.

13 See, e.g., 113 U. PA. L. REv. 284 (1964); cases cited note 15 infra.

14 New York Times Co. v. Sullivan, 376 U.S. 254, 278-79 (1964).

15 Compare Barwick v. Wind, 203 Ga. 827, 831, 48 S.E.2d 523, 526 (1948), with Parsons v. Age-Herald Publishing Co., 181 Ala. 439, 450, 61 So. 345, 350 (1913). The "fair comment" privilege protects expression of opinions criticising the public acts of public men but does not protect the publication of a defamatory misstatement of fact.

16312 U.S. 552 (1941), affrming 111 F.2d 1 (8th Cir. 1940), reversing Jay C. Hormel, 39 B.T.A. 244 (1939). 
on section 22 (a) ${ }^{17}$ of the Revenue Act of 1934 to tax certain family trusts when he had relied solely on sections 166 and $167^{18}$ at the hearing. Between the hearing and appeal of Hormel, the Supreme Court in another case, Helvering v. Clifford, ${ }^{19}$ had changed the judicial interpretation of section 22(a), rendering judgment for the Commissioner. At the hearing in the Clifford case, whose order was promulgated four months prior to that of the Hormel hearing, the Commissioner had successfully defended an assessment of a similar family trust under the broad provisions of section $22(a),{ }^{20}$ and that decision was reversed by the Eighth Circuit after the hearing in Hormel. It is significant that at the hearings of both Hormel and Clifford the Commissioner was represented by the same attorney, yet the Supreme Court considered, but did not utilize, the doctrine of waiver. ${ }^{21}$

In Johnson v. Zerbst ${ }^{22}$ the Supreme Court defined waiver as "an intentional reliquishment or abandonment of a known right or privilege." The court in the Butts case purported to adopt the same definition. ${ }^{23}$ In Johnson a convicted counterfeiter had petitioned for a writ of habeas corpus. The opinion pointed out that courts should indulge every reasonable presumption against waiver of fundamental constitutional rights ${ }^{24}$ and that an accused may waive his constitutional right to the assistance of counsel only competently and intelligently. ${ }^{25}$

The Johnson definition has been used in both criminal and civil cases. When a party can prove that he did not intentionally waive a contractual right ${ }^{26}$ or that he did not have the actual knowledge of the facts necessary

17 Revenue Act of 1934, ch. 277, §22(a), 48 Stat. 686-87.

18 Revenue Act of 1934, ch. 277 , $\S \$ 166,167,48$ Stat. 729-30.

19309 U.S. 331 (1940), reversing 105 F.2d 586 (8th Cir. 1939), reversing George B. Clifford, Jr., 7 P-H Tax Ct. Mem. โ 38,335 (1938).

20 The holding of the Board at the Clifford hearing seems much narrower than the Supreme Court decision affirming it. It is unlikely that Hormel would have been controlled by the Board's decision in Clifford even if the Commissioner had asserted liability under $\$ 22$ (a), Jay C. Hormel, 39 B.T.A. 244, 247 (1939) (dictum), just as it is unlikely that the present case would have been controlled by New York Times if the newspaper had won in the state courts (even if Curtis and Nerw York Times had been in the same jurisdiction). See New York Times Co. v. Sullivan, 273 Ala. 656, 661 (1962) (counsel's constitutional arguments).

21 Hormel v. Helvering, 312 U.S. 552, 557 (1941).

22304 U.S. 458, 464 (1938).

23351 F.2d at 711.

24 Johnson v. Zerbst, 304 U.S. 458, 464 (1938).

25 Ibid.

28 In Chambers \& Co. v. Equitable Life Assur. Soc'y, 224 F.2d 338, 345 (5th Cir. 1955), the Fifth Circuit, in holding that an insurance company had not waived its rights under a contract by the acceptance of a stand-by fee, because it had never intended to waive the time limit for performance of the contract, stated the Johnson definition of waiver and said: "The right, privilege or advantage allegedly waived must be in existence and be known to exist by the party possessing it, and this party must intentionally and voluntarily relinquish such right, advantage or benefit." 
to relinquish the right intentionally ${ }^{27}$ courts have held that there is no waiver of a known right. When the right is given by federal or state law, however, there is usually an irrebuttable presumption that a party knows the law and his rights under it. ${ }^{28}$ An exception to this presumption is often made with respect to constitutional rights in criminal cases. In many situations it has been held that a criminal defendant must have actual knowledge of his constitutional rights in order to waive them. ${ }^{29}$ In the Butts case the court inferred from circumstances which were not part of the record and upon which, of course, no evidence had been introduced, that Curtis knew of the constitutional argument being urged in New York Times and intentionally waived it. ${ }^{30}$ By means of this inference the court constructed an irrebuttable presumption that Curtis had actual knowledge of the argument and intentionally chose not to use it, a presumption as strong as that which ordinarily operates with regard to knowledge of the law. The court, however, although it presumed knowledge of the arguments raised in New York Times, did not seem to hold that Curtis was bound to raise those arguments, but only that it had to raise some first amendment defense. $^{31}$ If the court meant that any first amendment defense would have been adequate, then it presumed at least that Curtis intentionally chose not to use such a defense. This is the same presumption which normally applies to arguments not asserted at trial when the applicable law has not changed. An examination of some cases which

27 In Compania Constructora Bechtel-McCone, S.A. v. McDonald, 157 F.2d 749 (9th Cir. 1946), the court held that appellant company had not waived its right to fire appellee under an employment contract by ordering him back to work because it did not know all the facts of his prior insubordination. In Michener v. Johnston, 141 F.2d 171, 175 (9th Cir. 1944), the court said: "Waiver is a question of ultimate fact rather than of law." But see Parden v. Terminal Ry., 377 U.S. 184 (1964), holding that the state of Alabama had waived its sovereign immunity to suit by entering into activities subject to congressional regulation-the operation of a railroad. However, the Court did not repudiate the Johnson definition of waiver as necessarily knowing and intentional, because it found that Congress in enacting the Federal Employers' Liability Act, 35 Stat. 65 (1908), as amended, 45 U.S.C. $\$ \$ 51-60$ (1964), had intended that a state would automatically waive its sovereign immunity in such circumstances.

28 Holmes, The Common Law 47-48 (1909).

29 Fay v. Noia, 372 U.S. 391, 439 (1963) ; Williams v. Alabama, 341 F.2d 777, 780-81 (5th Cir. 1965). Even in the case of a misdemeanor the Fifth Circuit has held that the right to counsel can be waived only intelligently and competently, Harvey v. Mississippi, 340 F.2d 263, 269 (5th Cir. 1964).

30351 F.2d at 711. In its petition for rehearing en banc Curtis included affdavits of its general trial counsel and of the Alabama law firm which had represented the New York Times Company which stated that they had never discussed the constitutional argument asserted after New York Times. Counsel for Curtis swore that he was not even aware of the arguments being urged in the New York Times case. Brief for Appellant in Support of Petition for Rehearing, pp. 37-42. It is also noteworthy that the petition for certiorari in New York Times did not claim the precise constitutional right which was eventually enunciated by the Supreme Court. See 351 F.2d at 724 n.19 (dissenting opinion).

31351 F.2d at 711. "What the Supreme Court would, or might, hold in Times was not decisive. What was important was that Curtis had to invoke any constitutional claims in an appropriate way, and at an appropriate time." 
consider the doctrine of waiver when the law has changed after trial will reveal other Butts alterations in the meaning of the words which define waiver.

In Walker v. Peppersack, ${ }^{32}$ a federal habeas corpus case in which the petitioner claimed that illegally seized evidence had been admitted in his Maryland state trial, the Fourth Circuit said: "At the time of Walker's trial and first appeal, it is clear that he did not intentionally abandon a knowen right since there was then no such right for him to abandon. That was before the Supreme Court's decision in Mapp." In United States ex rel. Mancini $v$. Rundle ${ }^{33}$ the Third Circuit, in allowing the petitioner to bring federal habeas corpus, said: " $[\mathrm{A}] \mathrm{t}$ the time of trial the Pennsylvania Courts allowed illegally obtained evidence to be admissible. As the law was then applied, it would have been a futile gesture for Mancini to have moved to suppress the evidence prior to trial or to have objected to its admission at the trial on the grounds of unreasonable search and seizure." So in the Butts case it would have been almost certainly futile for Curtis to have asserted its alleged constitutional right, which had not then been recognized. Walker and Mancini assume that where there is no remedy there is no right, and that constitutional rights do not accrue until the courts have articulated them. In Butts, although a vaguely defined constitutional argument might have been known to Curtis, no such right could have been relied upon, because no first amendment right to make defamatory statements had been declared at that time. However, the court did not hold that Curtis waived that right, but that it waived the right to assert the constitutional argument. ${ }^{34}$ The difference is subtle, but important; for the court in that way kept its holding within the words of the Johnson definition of waiver. After presuming knowledge of the constitutional argument and a conscious determination not to use it, the court held that Curtis intentionally waived a known right to assert that argument. Mancini and Walker disagree with the Butts case on this point. In those cases the courts could have said that because for years $W$ olf $v$. Colorado ${ }^{35}$ had been attacked before the Supreme Court, counsel for petitioner must have known of the argument that illegally seized evidence should be excluded from state trials, and that therefore counsel had waived the right to move to exclude such evidence. The courts, however, based their decisions on the assumption that the right which must be known and intention-

82316 F.2d 119, 127-28 (4th Cir. 1963) (overruled on other grounds by Linkletter v. Walker, 381 U.S. 618 (1965)).

33337 F.2d 268, 274 (3d Cir. 1964) (overruled on other grounds by Linkletter v. Walker, 381 U.S. 618 (1965)).

34 The court said: "[W]e hold that Curtis has clearly waived any right it may have had to challenge the verdict and judgment on any of the constitutional grounds asserted in Times." 351 F.2d at 713. "The dissenting opinion on the other hand refers to the primary right in its discussion of waiver: "I do not think the defendant may be said to have waived by 'silence' a constitutional right not enunciated at the time ..." Id. at 723-24.

35338 U.S. 25 (1949). 
ally relinquished was not the secondary right to move to suppress illegally seized evidence, but the primary right to exclude that evidence. In the Butts case the right to criticize a public official in his official capacity in the absence of actual malice is the relevant right, and at the time of trial such a right did not exist. The Fifth Circuit itself, in Cobb v. Balkcom, ${ }^{36}$ said: "The purported waiver here must be tested . . . in the light of whether there was'. . . an intentional relinquishment or abandonment of a known right . . . i.e., the right to indictment by a grand jury and trial before a traverse jury from which Negroes are not . . . systematically excluded." The court did not refer to the right to challenge a segregated jury array, but to the right to have an unsegregated jury.

In attempting to understand what the court did in the Butts case, it is important to realize that the court felt certain, not without justification, that Curtis Publishing Company fully deserved to lose a substantial amount of money. Thus the court, after a statement of the facts which put Curtis in the worst possible light,, ${ }^{37}$ said: "As the trial judge saw it: "The article was clearly defamatory and extremely so .... The guilt of the defendant was so clearly established by the evidence in the case so as to have left the jury no choice but to find the defendant liable.' We wholeheartedly agree with that appraisal." 38 The question then became on what theory Curtis should lose. ${ }^{39}$

A consideration of the reasons for the rule that errors unasserted at trial are waived will help to show whether there was any compelling procedural reason for the Butts court to isolate the case on its own facts and to depart from the previous use of the waiver definition. Generally, the

38339 F.2d 95, 101 (5th Cir. 1964).

37 [T] he editor-in-chief . . [embarked] upon a policy of "sophisticated muckraking" ....

[The writer] and Curtis knew publication of the article "would ruin Coach Butts' career"....

Curtis chose not to use as a witness either the author of the article or any of its editors who had made contributions to the article after it had been submitted. Nor did it use the Atlanta sports editor who had assisted in the preparation of the story. As one of its principal witnesses it called upon George Burnett, who was known by Curtis to have been convicted of writing bad checks ....

351 F.2d at 705-06.

\section{Id. at 707.}

39 If the court had found that Butts was not a public official as contemplated by New York Times, Curtis would have lost; if it had found that the jury instructions considered as a whole contained an adequate charge on the issue of actual malice, Curtis would still have lost. But perhaps the majority was convinced by dissenting Judge Rives' arguments that Butts was a public official, $351 \mathrm{~F} .2 \mathrm{~d}$ at 723,725 , and that the charge on malice was unconstitutional, id. at 723. In any event the court was convinced that the evidence "was sufficiently strong to justify the jury in concluding that what the Post did was done with reckless disregard of whether the article was false or not." Id. at 719. Certain of the justice of the verdict the court probably wanted to avoid a remand which would give Curtis an opportunity to revise its trial strategy and which would probably cost Butts many thousands of dollars, because of the high cost of litigation. See Chadbourn \& Levin, Cases on Civil Procedure $427-63$ (1961). 
purposes of the rule are: to protect the opposing party from the prejudice of surprise or delay, to prevent a party from unfairly obtaining a new trial on the grounds of unasserted errors which the trial judge could have corrected, and to prevent undue expense and delay in the judicial process. ${ }^{40}$ Even if any of these reasons were applicable in the Butts case, they should not have been controlling; the purpose of considering them is not to justify, but if possible to explain, the court's decision.

As soon as New York Times was decided, Curtis moved for a new trial, and the trial judge considered the constitutional argument on its merits. It cannot be said that Butts would have been the victim of surprise if the appellate court had considered the argument on its merits, for he had ample time to prepare the point between that time and appeal. Curtis did raise the point while the trial judge still had jurisdiction; thus the trial judge had an opportunity to decide all the questions of law before appeal, and the appellate court had the benefit of his decision. Even if Curtis had raised the constitutional argument at trial, the trial judge would obviously have denied its applicability, as he did in denying the motion for new trial; so the circuit court would have had to decide the question on its merits, and the necessity for a new trial would have been no more or less likely than in the circumstances of the Butts case. Of course, if the trial judge had decided that New York Times did apply and that a new trial was necessary, Curtis' failure to assert the constitutional argument at trial might arguably have occasioned a delay. But it is diffcult to see how the district judge could have avoided denying the constitutional claim before the decision in New York Times; thus a strategy of withholding the argument until after trial would not have created a greater possibility of new trial than if the argument had been asserted at trial. Even if Curtis had raised a constitutional claim at trial, and the trial judge had framed a charge accordingly, it is extremely unlikely that the charge would have approximated the formula enunciated in New York Times.

In any event, even if these considerations did argue persuasively for the invocation of waiver, they should not operate where the fundamental law has changed between trial and appeal. Although the fiction that every man, and especially every lawyer, knows the law has been frequently cast aside in criminal cases affecting constitutional rights, it is ordinarily necessary for the orderly administration of justice. But such a fiction is neither necessary nor fair in cases where the alleged right has yet to become law. The effect of the Butts decision may be to force counsel not only to know of, but to assert at trial, arguments which are then being urged on appeal in other cases. Even if counsel is aware of an argument, he may consider it poor trial strategy to assert a claim which has no chance of success unless

40 Atlantic Brewery Co. v. William J. Brennan Grocery Co., 79 F.2d 45, 47 (8th Cir. 1935); see McCandless v. Furlaud, 293 U.S. 67, 74 (1934); Hutchinson v. Fidelity Inv. Ass'n, 106 F.2d 431, 436 (4th Cir. 1939); Note, 64 HARv. L. REv. 652, 654-55 (1951). 
an appellate court later decides that it is a valid one, particularly if he thinks he can win without it. He might feel, for example, that too many alternative theories would hurt his case by confusing the jury or would annoy a certain trial judge by making the trial unnecessarily complex. The cautious lawyer, with due regard for his client's interests, will now include in his pleadings or requests for jury instructions a plethora of arguments, whether or not there is authority to support them. Since such claims will almost invariably be denied, their assertion is not likely to speed the administration of justice. 